
\title{
CIÊNCIANATURA
}

\section{Artisanal fishing characterization and spatio-temporal occurrence of ma- rine shrimp (Crustacea, Decapoda, Penaeidae) in the littoral of Lucena, Paraíba, Brazil}

Glória Cristina Cornélio do Nascimento ${ }^{1}$, Dimitri de Araújo Costa ${ }^{1}$, Raquel Ferreira de Sá2 , Martin Lindsey Christoffersen ${ }^{3}$ e Maria Cristina Basilio Crispim ${ }^{3}$

${ }^{1}$ Pós Graduação em Desenvolvimento e Meio Ambiente, Universidade Federal da Paraíba, Paraíba, Brasil

${ }^{2}$ Centro de Ciências Exatas e da Natureza, Universidade Federal da Paraíba, Paraíba, Brasil

${ }^{3}$ Departamento de Sistemática e Ecologia, Centro de Ciências Exatas e da Natureza, Universidade Federal da Paraiba , Paraíba, Brasil

\begin{abstract}
The present study distinguishes types of fishing activities. It records the most economically exploited shrimps in the municipality of Lucena, Paraiba, Xiphopenaeus kroyeri ("espigudo"), and Penaeus schmitti (white shrimp). From October 2014 to October 2015, samples containing $700 \mathrm{gr}$ of shrimp were collected at three sites of artisanal fishing. Data on temperature, ammonium, nitrate, nitrite, chlorophyll-a, salinity, $p H$, and dissolved oxygen were recorded. Two different shrimp species are commercially used in the region, of 2,628 sampled individuals, X. kroyeri predominated, with 1,957 individuals, followed by P. schmitti, with 671 individuals. At localities 1 (in Lucena beach) and 2 (Fagundes beach) both species were present, the X. kroyeri being predominant, but at locality 3 (Costinha beach) only the P. schmitti was recorded. The regional wet season influenced salinity during the months of the year, producing positive and/or negative correlations among species found at each locality depending on what was analyzed. It is relevant to understand the relationship between fishing resources and environmental variables which provide information about fishing dynamics and permits the development of strategies for the maintenance of stocks and fishing areas, as well as permitting the establishment of public regulations for the better preservation and conservation of marine areas and estuaries on which many species depend for the completion of their life cycles.
\end{abstract}

Keywords: Fishing gear, Xiphopenaeus kroyeri, Penaeus schmitti. 


\section{1 introduction}

Most of the world's biodiversity occurs in coastal and oceanic regions, consequently, these marine areas are suffering some form of aggression resulting from human activities. Important fishing resources are being drastically reduced or are on the risk of extinction (HARARI; ABREU, 2007). Marine shrimps represent one of the most exploited resources in coastal regions of the world oceans, including the Brazilian littoral (BOCHINI et al., 2014). They represent the second most important fishing resource, being surpassed only by lobster fishing (SANTOS et al., 2013).

Decapods are among the most investigated groups of animals, bearing in mind their conspicuous presence in aquatic ecosystems as well as their importance as food for humans (VOGT, 2012). Some species of marine shrimps have a large geographical distribution, while others are endemic (HOLTHUIS, 1980). More detailed knowledge on these resources becomes relevant for strategies of monitoring and conservation, bearing in mind the reality of the place and the characteristics of the surroundings in which these shrimps live. Information on fishing resources may be determinant for the development of a better management plan, because species interact with the preservation of the habitats in which they live, thus providing scientific subsidies for an efficient administration of these resources (HECKLER et al., 2013).

Shrimp fishing represents a significant important economic, historical, social, and cultural enterprise, being practiced on a large scale along the Brazilian coast, the Potiguar Indians (meaning shrimp-eaters) already fished shrimp even before the Portuguese first arrived in Brazilian territory (BRANCO, 2005). The impact of this fishing activity has caused losses of biomass and of biodiversity of several species of shrimp in different coastal regions (BOCHINI et al., 2014). Besides, these environments have been suffering increasing impacts, such as by pollution, climatic changes, and shifts in the composition of the biota from these areas (HARARI; ABREU, 2007), understanding the distribution of shrimp with environmental factors may help us to provide sustainability for this fishing activity (MARTINS et al., 2015; PÉREZ-CASTAÑEDA; DEFEO, 2005).

This paper aims to monitor some artisanal shrimp fishing, using drag-nets to record the species of marine shrimp which are economically important in the municipality of Lucena, in the State of Paraíba, during period of a year (2014-2015), and to record the results of the drag-nets, noting possible changes in abundance, due to different abiotic conditions in the environment.

\section{Material and Methods}

The municipality of Lucena is located in the northern coast of the State of Paraíba. It occupies an area of $88,944 \mathrm{~km}^{2}$, extending for about $16 \mathrm{~km}$ along the coast (FERNANDES et al., 2011). It has a population of 11,545 inhabitants (INSTITUTO BRASILEIRO DE GEOGRAFIA E ESTATÍSTICA, 2010). In order to document spatio-temporal patterns related to environmental variables, three collecting localities were established: one locality (L1) was the furthest, relative to the mouth of the Rio Paraíba (Lucena), L2 was in the middle (Fagundes), and L3 being the nearest to the mouth (Costinha) (Figure 1).

Figure 1-Study area. L1 (Lucena), L2 (Fagundes), and L3 (Costinha)

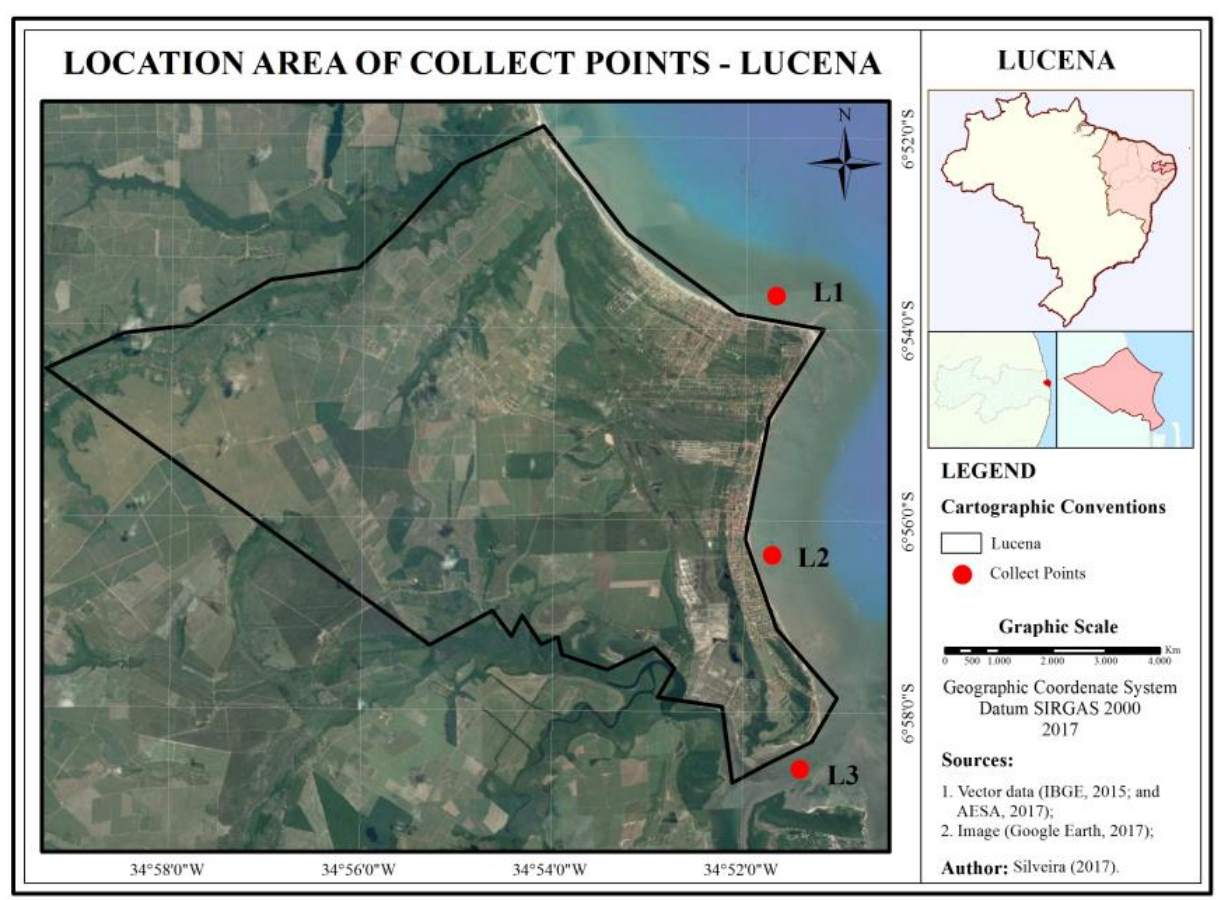


These localities were chosen because they have the largest shrimp-fishing input, thus assuring the representativeness of this activity in our study (BAIL; BRANCO, 2007; FERNANDES et al., 2014). Sampling was conducted monthly, from October 2014 to October, 2015, contemplating the modes of artisanal shrimp fishing for this resource. To evaluate the period of fishing recruitment, a random throw and a sample of 700 gr was taken from the catch (SANTOS et al., 2001; MENDONÇA; BARBIERI, 2010). The species of shrimp were sorted (qualified) according to criteria of the fishermen (length), taking into account a chosen commercial category (MENDONÇA; BARBIERI, 2010). The samples were weighed, conserved with ice, and later transported to the laboratory, LABEA (Laboratório de Ecologia Aquática)/DSE/UFPB. Species were identified using the specialized literature (DALL et al., 1990). Each individual was weighed with a precision weighing-machine (mg) and measured with a pachymeter. Total length (TL) in $\mathrm{mm}$ is from the tip of the rostrum to the tip of the telson. Cephalothorax length (CL) was measured from the tip of the rostrum to the posterior margin of the carapace has proposed by Lopes et al. (2010).

The research is in accordance within the norms of the Nacional Health Council (CNS) 466/2012 and was submitted to the Ethic Commission of the Federal University of Paraíba and approved with the Protocol 0211/2015, CAAE: 445935154.8.0000.5188.

For the analyses of water parameters close to the marine substratum, samples were collected with a Van Dorn recipient (3L) for temperature and salinity (ROBERT; BORZONE; NATIVIDADE, 2007). These measurements were taken with a digital thermometer and with a manual refractometer. Chlorophyl- $a$ was analyzed with the method used by Lorenzen (1967). For the analyses of nutrients present in the water, measurements of nitrogenous compounds (ammonium, nitrate, nitrite) were made: ammonium by the method of fenol; nitrate by the method of cadmium reduction; nitrite by the colorimetric method, and phosphate (orthophosphate) by the method of perosulfate. These analyses followed the patterns established by Standard Methods for examination of water and wastewater (CLESCERI et al., 1998). Pluviometric data were collected from the site AESA (Agência Executiva de Gestão das Águas do Estado da Paraíba).

\subsection{Data analyses}

The data obtained were tabulated in Excel spreadsheets and then used to generate graphs for the species analyzed in relation to the environmental variables. Next the physic-chemical data were compared with samples from each collecting locality, in order to understand the shrimp dynamics along time. All correlations were carried out with the use of the statistic program PAST, version 3.13 (HAMMER et al., 2001). The test Shapiro-Wilk was used to verify the normality of the data and the Levene homocedasticity test was realized to compare variance among samples. The data turned out to be parametric ( $<<0.05$ ), consequently, the coefficient of Spearman was calculated to check the correlation among the environmental variables and the shrimp species. PCA graphics were used to show these correlations.

\section{Results and Discussion}

In the municipality of Lucena the dominant type of fishing is maritime, carried out by most of the fishermen and the shrimp is the product which is most sought out and caught by two types of net: shrimp-net and a beach drag-net (GARCÍA; MEDEIROS, 2013) (Figure 2). At localities 1 and 2 the beach drag-net predominates (with mesh size of 15 to $20 \mathrm{~mm}$ between knots), while at locality 3 only shrimp-nets (with mesh size between 25 to $30 \mathrm{~mm}$ between knots), are used from boats. The environmental and spatial characteristics of these places determine the fishing art chosen to catch shrimp, where as in Costinha (L3), only the white shrimp is present which reaches a larger size, making the use of shrimp nets a better choice.

Figure 2-Types of nets used to fish marine shrimp in the municipality of Lucena, Paraíba. Shrimp net (A), beach drag-net (B)
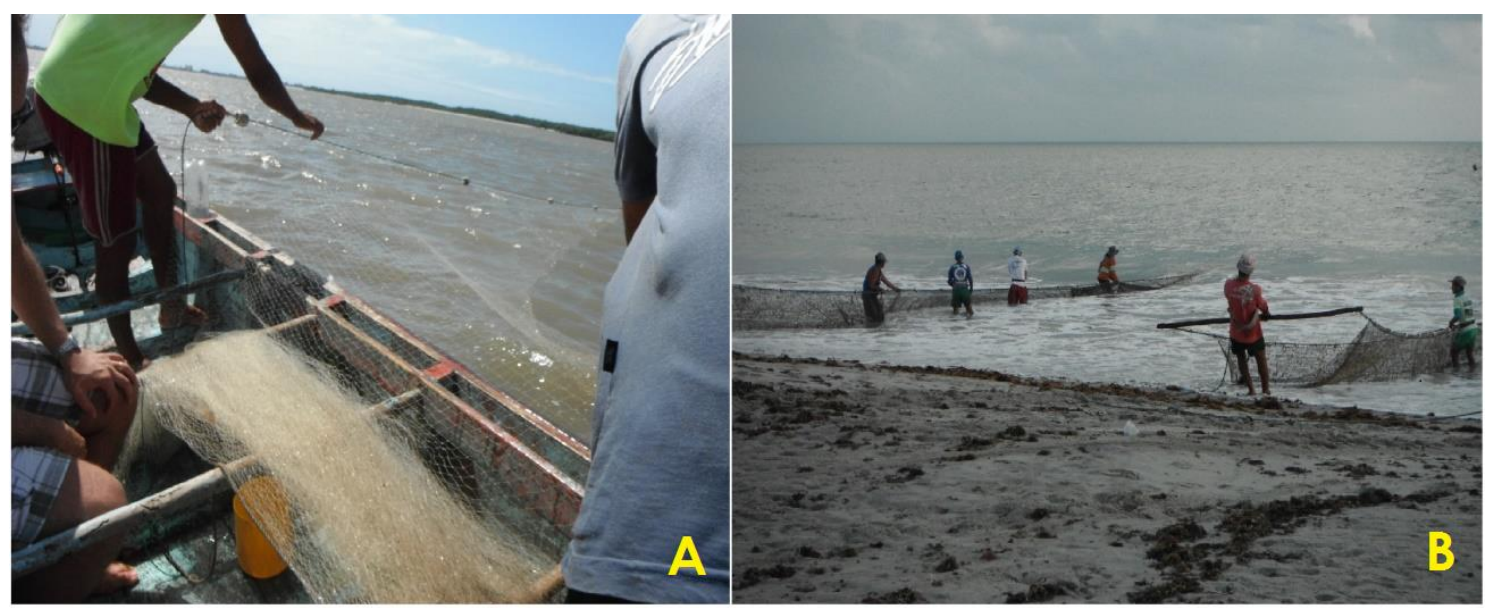

Photos: Glória Cristina Cornélio do Nascimento, 2014 
In all 2,628 individual shrimps were analyzed, belonging to two species of commercial importance: Penaeus schmitti $(n=671)$ and Xiphopenaeus kroyeri $(n=1.957)$ (Table 1). The species were deposited in Laboratório de Invertebrados Paulo Young at Departamento de Sistemática e Ecologia, Campus I, Federal University of Paraíba: Xiphopenaeus kroyeri (Heller, 1862) (UFPB 7351); and Penaeus schmitti (Burkenroad, 1936) (UFPB 7352). Penaeus schmitti may be cited in some papers such as Litopenaeus schmitti, but we use the name adopted in WoRMS (World Register of Marine Species) (FRANSEN, 2015), based on the revision of Pérez-Farfante and Kinsley (1997).

Table 1: Distribution (abundance) of species of shrimp (n) of economic importance captured at three localities

(L1 = Lucena; L2 = Fagundes; L3 = Costinha) in the municipality of Lucena, Paraíba

\begin{tabular}{c|c|c|c|c}
\cline { 2 - 5 } & \multicolumn{4}{c}{ Collecting localities } \\
\hline Species & L1 & L2 & L3 & Total (n) \\
\hline Penaeus schmitti (n) & 149 & 170 & 352 & 671 \\
\hline Xiphopenaeus kroyeri (n) & 1.315 & 642 & 0 & 1.957 \\
\hline Total (n) & 1.464 & 812 & 352 & 2.628 \\
\hline
\end{tabular}

At L1 (Lucena), only nine collections were made, because fishing activities were not conducted on some days in November 2014, December 2014 and April 2015. At L2 (Fagundes), only seven collections were made; fishing at this locality was quite irregular and did not occur in February, May, August, September, and October (2015). At L3 (Costinha), eleven collections were made, only the month of February 2015 was left out due to a lack of shrimp catch. Highest capture values were recorded for L1 and L2, the quantity of X. kroyeri being the most representative. This species did not occur at L3.

The shrimp $X$. kroyeri is known locally in Lucena as "espigudo". In other localities in Brazil it is known as sea-bob-shrimp (SANTOS; BRANCO; BARBIERI, 2013; FERNANDES; KEUNECKE; DI BENEDITO, 2014; VIANA; CAMARGO; DUTRA, 2015). The geographical distribution of this species occurs in the Western Atlantic from North Carolina (EUA) to the State of Santa Catarina in Brazil. Brazil and Guyana represent the countries with the largest captures of this species (HOLTHUIS, 1980).

This species occur in environments of high salinity and high discharge of continental nutrients also correlates with its distribution and abundance (DIAS NETO, 2011). We observed a reduction in the number of "espigudo" catched as the habitat changed into lower salinity and as the locality L3 was closer, since is the site with lower salinity at all. In northeastern Brazil (Rio Grande do Norte, Pernambuco, and Paraíba) Santos et al. (2013), noted that "espigudo" has its life cycle of type 3, that all life phases occur in marine waters. Other studies confirm this observation (CASTRO et al., 2005; COSTA et al., 2007). As L1 is more distant from the influence of the mouth of the Paraíba river estuary, the salinity at this locality is higher $(\bar{x}=37.3)$, while the lower salinity at locality L3 $(\bar{x}=33.8)$ is apparently the reason for the absence of the species at this locality.

Shrimp fishing at locality L3 is directed exclusively towards the species Penaeus schmitti, known both locally and in other parts of Brazil as the white shrimp (SANTOS et al., 2008). In the State of Maranhão the geographic location was one of the factors that confirmed this fact, the largest shrimps were found on the oceanic side of the island of São Luís, while the smallest specimens occurred in the bay of São José (PORTO et al., 1988), showing that the proximity of inland waters do not favor this species. In studies conducted in maritime regions and along the estuarine complex in Santos, in the State of São Paulo, immature or developing females of smaller size were captured in the estuarine region, while females with mature or empty ovaries were found in marine habitats. These data indicate that migration occurs from less saline (estuarine) habitats to oceanic waters of higher salinity (open sea) during the reproductive period (SANTOS et al., 2008). These data also explain why the species was found in both saline and estuarine conditions in our study.

\subsection{Biometry and fishing recruitment}

Regarding biometry carried out, the "espigudo" showed a period of higher total length (TL) at L1 during the months of October 2014 and March 2015. Individuals of a smaller length (TL) reflect the previous period of egg release, with newly recruited individuals being caught after the fishing trip in June, July and September 2015 (Figure 3). The months of October 2014 to March 2015 should then represent the peak reproductive period for this species. This estimate corroborate with the research of Coelho and Santos (1993), they found that "espigudo" shrimp presents intense reproductive period in spring and summer that in northeast Brazil are from September to March. The white shrimp had a different behavior from the "espigudo" in L1. The largest TL appeared practically during the whole period, showing that most captured individuals on the fishing trips represent adults in the reproductive period or just after reproduction (Figure 3). The white shrimp presents a life cycle classified as type 2, meaning that eggs, larvae and adults use marine environment and juveniles and post-larvae use estuarine waters (DALL et al., 1990). During the month of August there were no male individuals in the sample, suggesting some type of migration, which could be reproductive. 
Figure 3 - Box-plot graphs of total length (TL) of the two species of shrimps at locality 1 (Lucena) - 2014/2015

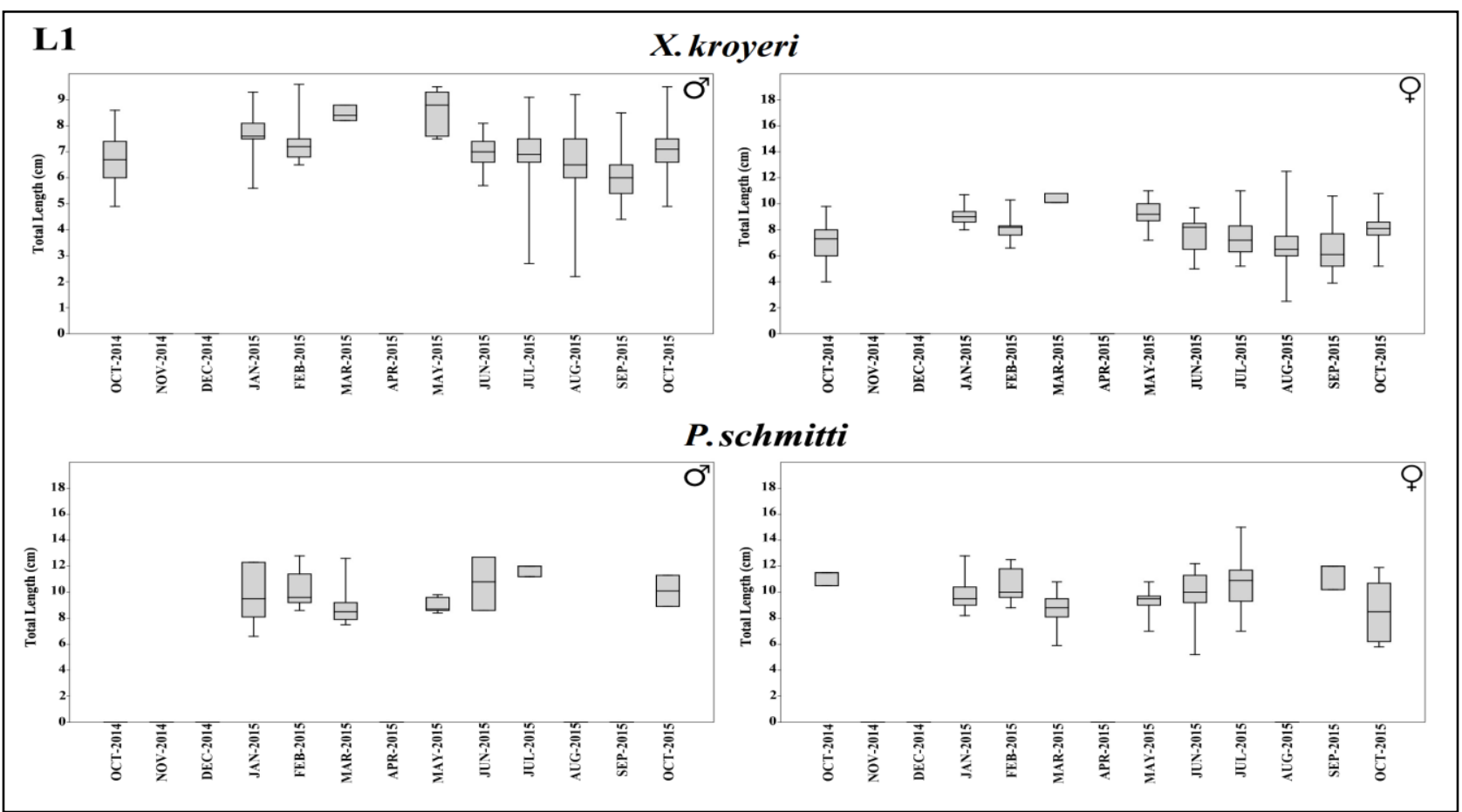

In L2 the data analysis for biometrics was prejudiced due to the inconsistency in shrimp fishing. Although it was noted that in January and April shrimps "espigudo" were not seen (Figure 4). As L2 is a site with major interference of estuarine waters and the related months showed the period that these individuals are in reproductive phase, the tendency of these shrimps is to look after higher salinity areas. The sighting of white shrimp was larger than that of "espigudo" in L2, showing a less favorable habitat for this later species at this place. Salinity may represent a limiting factor, as this locality is still affected by the estuary. In the months of October, November, and December 2014, P. schmitti, grew to their longest lengths, as could be

Figure 4 - Box-plot graphs pf TL (mm) of both species of shrimp at locality 2 (Fagundes) - 2014/2015

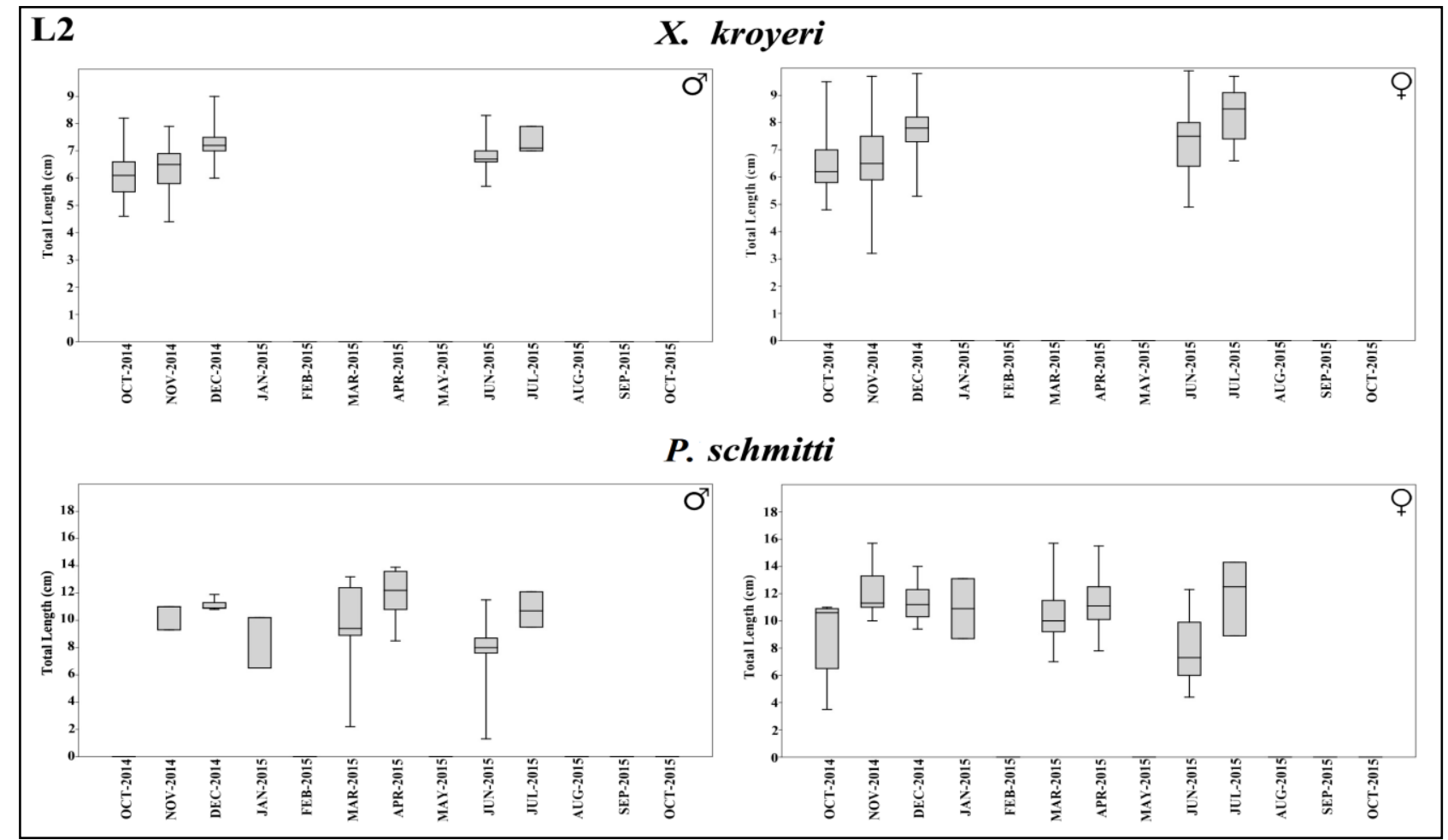


Figure 5 - Box-plot graphs of the TL (mm) of specimens of $P$. schmitti at locality 3 (Costinha) - 2014/2015

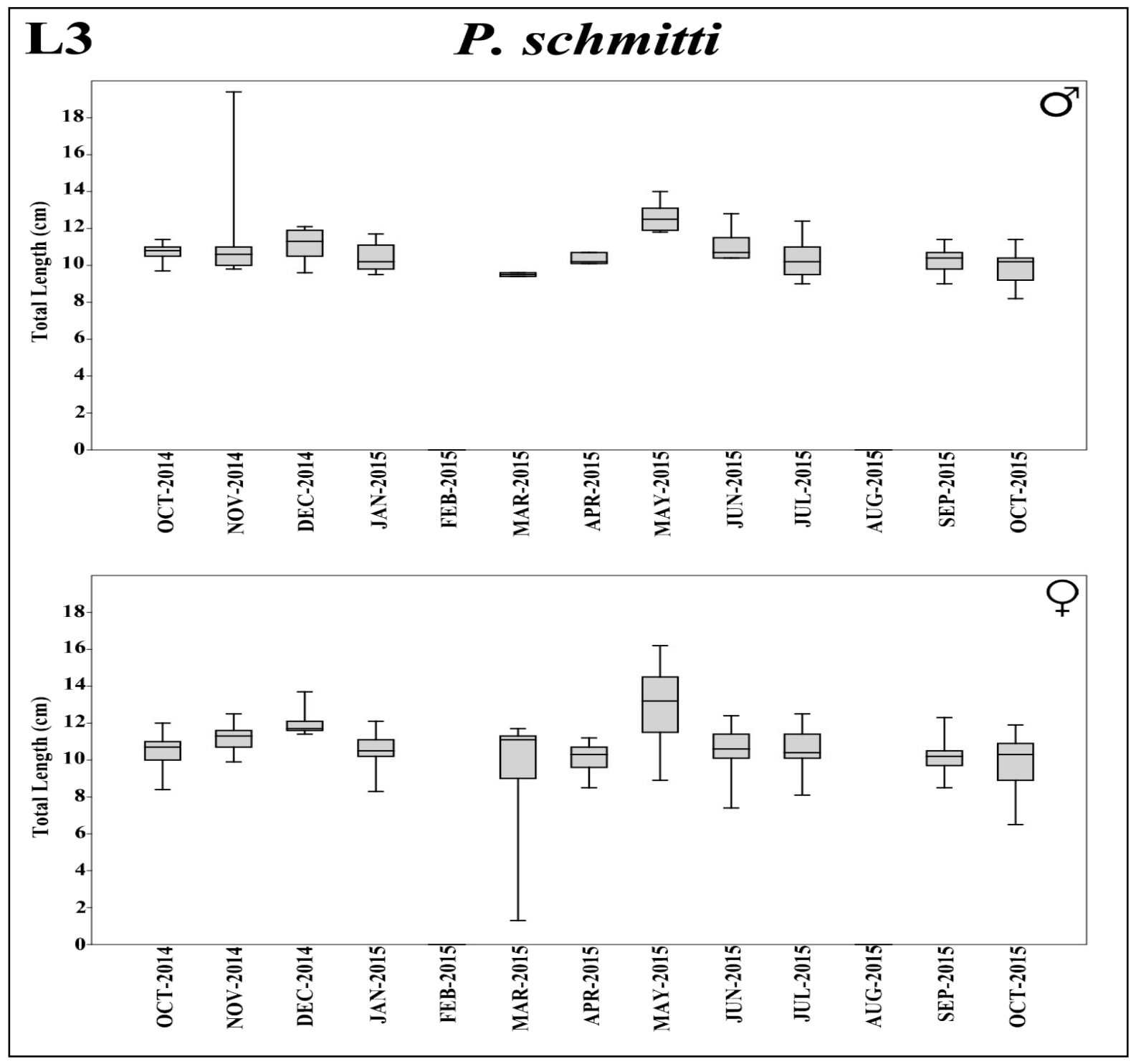

seen by biometrical measures. Females were largest in March and April 2014. Consequently, the smallest individuals should appear in the following months (Figure 4), which is a result of species recruitment. This was seen in L1, where the smallest individuals were collected in July and August 2014.

In L3, white shrimp fishing was more frequent. The largest individual occurred in the months of November and December 2014 and May 2015. Due to the samples being collected in an estuarine environment, the capture of these individuals is directed to juveniles and adults that migrate to deeper waters off the coast. Furthermore, the size of the mesh of the shrimp nets influences the sizes captured (Figure 5), making it more difficult to estimate the period of recruitment of this species at this place, because the younger individuals are not catched. To improve the data precision an independent fishing could be realized, to better understand the recruitment, but the aim of this work was to follow the fisherman fishery. According to Moura et al. (2003), the fishing production in this locality of the municipality of Lucena is directly related to the influence of mangroves and estuaries and results in the white shrimp penetrating this type of environment during the first stages of the life cycle, completing its cycle at the reproductive stage in marine environments.

The "espigudo" has its reproductive peak in northeastern Brazil during the months of February to June, while the white shrimp reproduced from July to September (DIAS NETO, 2011). Moura et al. (2003) studied the same locality as we did. They found that the average lengths $(\mathrm{mm})$ of the "espigudo" varied between 63,3 to $77,5 \mathrm{~mm}$ in males and from 68,4 to $80,9 \mathrm{~mm}$ in females, the largest sizes occurring from August to December, and the smallest sizes from May to July. The white shrimp had the largest average length, from 98,5 to $121,3 \mathrm{~mm}$ in males and from 101,8 to $134,5 \mathrm{~mm}$ in females, which suggested that the ideal period for banning the fishing of this species in the area should be from June to October as earlier proposed by Moura et al. (2003). 


\subsection{Environmental variables}

A Principal Component Analysis (PCA) was carried out for the two species of shrimp and the environmental variables in L1 and L2 in 2014 and 2015 (Figure 6), as well as for the white shrimp in L3 (Figure 7).

It was found that the white shrimp has a positive correlation with the months of March, April, and June, 2015 at L2, and June, 2015 at L1. This are the rainy period months. Furthermore this kind of shrimp is negatively related to the compounds nitrate, nitrite, ammonium, and phosphate, as well as with chlorophyl- $a$. These results suggest a possible low affinity of this shrimp with environments receiving a large input of nutrients as consequence of rain, as figures 8 and 9 show.

On the other hand, the "espigudo" shrimp has a positive correlation with the month of January, 2015 in L1, and a low positive correlation with nitrogenous and phosphate compounds; which may suggests higher affinity of this shrimp species with environments receiving higher fluvial effluents, environments which are richer in nutrients (Figure 6).

Figure 6-Principle Component Analysis of the two species of shrimp among the environmental variables, in L1 (Lucena) and L2 (Fagundes), in the years of 2014 and 2015

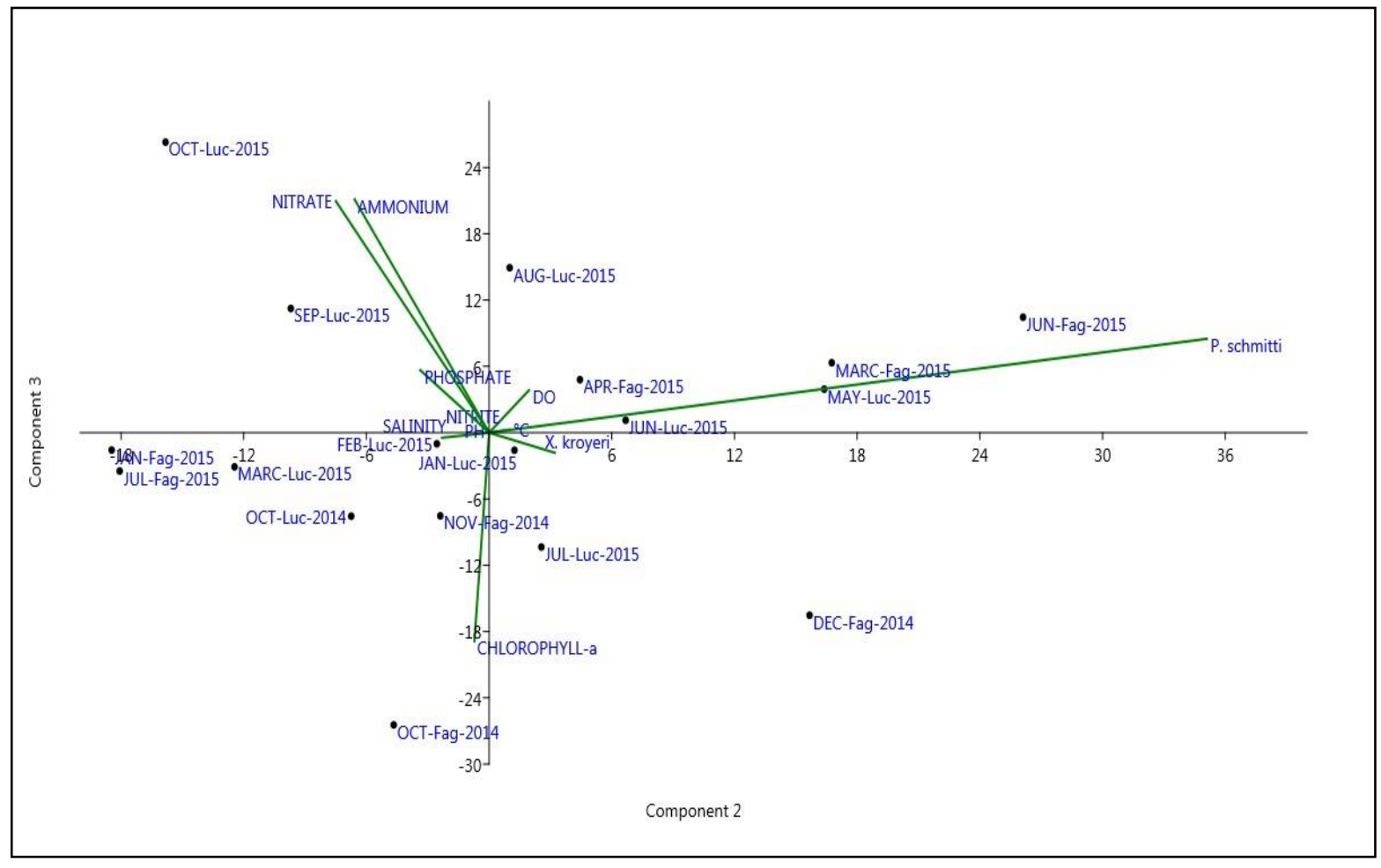

It was verified that the white shrimp correlates positively with the months of October and November/2014, January and July/2015. In addition, this shrimp correlates negatively with the nitrate and ammonia compounds (Figure 7).

A Spearman Correlation Test was also conducted among each environmental variable and each species of shrimp, for all sample localities. The "espigudo" presents a significant positive correlation with the compounds nitrite $(\mathrm{p}=0.012 ; \mathrm{F}=0.751)$, nitrate $(\mathrm{p}=0.002 ; \mathrm{F}=0.839)$ and ammonium $(\mathrm{p}=0.018 ; \mathrm{F}=0.723)$ in $\mathrm{L} 1$, corroborating the premise that this species prefers water with a higher trophic state. This same species presented a significant positive correlation with dissolved oxygen $(\mathrm{p}=0.041$; $\mathrm{F}=0.756$ ) in L2, showing that probably they support only mesoeutrophyzed waters, since in more eutrophyzed waters oxygen tends to decrease. On the other hand, the species $P$. schmitti presented a significant negative correlation with ammonium $(\mathrm{p}=0.034 ; \mathrm{F}=0.669)$ in $\mathrm{L} 1$. This same species presents a significant positive correlation with ammonium $(\mathrm{p}=0.021 ; \mathrm{F}=0.806)$ at L2. This difference may be due to different ammonium concentrations in the two environments, L2 being higher than L1, due its proximity with estuarine waters. So, a small increase in ammonium content may be favorable to $P$. schmitti, but when a certain level is too high it may inhibit growth. Ammonium determines the availability of nitrate, which interferes with primary production, Noriega et al. (2005) claimed that autotrophic organisms reveal preference for this kind of nutrients. Ammoniun and nitrate, in this sequence, offer energetic to phytoplankton (WHEELER; KOKKONAKIS, 1990). The richest oceanic areas are located in coastal regions, which represent more than half of the ocean productivity and are responsible for a large part of the world fisheries activities (BASTOS; FEITOSA, 2011). Changes in the environmental variables are highly relevant for the understanding of the distribution of marine species and crustaceans are organisms which are sensitive to these changes and they may directly influence the aspects of their population (BATE, 1888). 
Figure 7 - Principal Component Analysis of the white shrimp among environmental variables in L3 (Costinha), during the years of 2014 and 2015

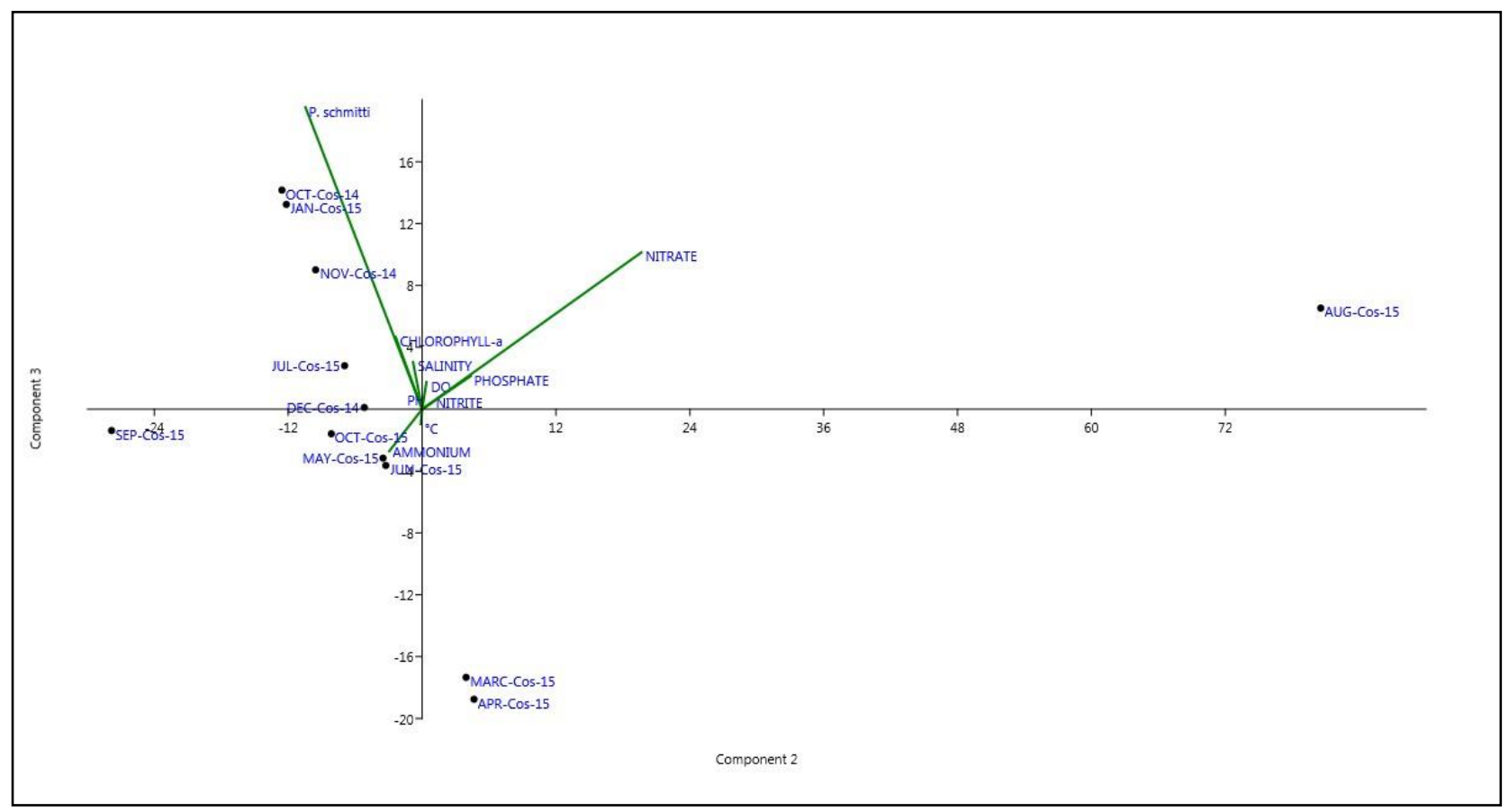

The measured correlations revealed positive correlations of nitrogenous nutrients and dissolved oxygen with the number of individuals of "espigudo" in L1. This fact is due to the increase of rainfall in the months of June, July and August, 2015 (Figure 8), in which all the nutrients are transported by freshwater rivers to the closest coastal regions (SOUSA; COCENTINO, 2004). Furthermore, areas closer to the coast present higher primary productivity in consequence of nutrient re-suspension, which is frequent in areas of shallow water. This phenomenon increases primary production in the water column (BRANDINI et al., 2007; PELIZZARI, 2000). In L1, nitrite varied from 0 to $0.79\left(\mathrm{mg} / \mathrm{L}^{-1}\right)$ in L1, nitrate from 0,09 to $33.41\left(\mathrm{mg} / \mathrm{L}^{-1}\right)$, and ammonium from 0.00 to 38.38 (mg/ $\left./ \mathrm{L}^{-1}\right)$. Dissolved oxygen $(\mathrm{DO})$ varied from 3.2 to 10.6 (\% saturation). Maximum values of nutrient and oxygen obtained were concentrated during the months of June to August, demonstrating its relation with the rainy season. The white shrimp has the inverse relation, showing that these animals prefer localities with less polluted waters.

In L2, the correlations differed because this area is a transition between the sea and the estuary. Salinity values varied between 33 and 38, chlorophyl- $a$ varied between 3.55 and $41.18\left(\mathrm{mg} / \mathrm{L}^{-1}\right)$, dissolved oxygen varied from 3.8 to $12.3\left(\mathrm{mg} / \mathrm{L}^{-1}\right)$, nitrate varied between 0,03 and $0,11\left(\mathrm{mg} / \mathrm{L}^{1}\right)$, and phosphate varied from 0.00 to $0.01\left(\mathrm{mg} / \mathrm{L}^{-1}\right)$. Although the behavior of the white shrimp was similar to that observed in L1, revealing its higher abundance in the months of lowest precipitation (Figure 9) that is, it prefers cleaner waters, because in the study environment, the higher values of nutrients were found in rainy months.

The availability of nutrients in coastal waters results mainly from the fluvial influx (TEOH et al., 2016; TROTT; ALONGI, 1999; YIN et al., 2000). The "espigudo" shows higher frequency when the fluvial input increases in coastal regions (PEREZ-CASTANEDA; DEFEO, 2004). Salinity and temperature are environmental factors that normally influence the frequency of these animals in coastal regions, determining the dynamics of their life cycle (SANTOS et al., 2006). This was confirmed in this study, as the species avoided the less saline water. In Ubatuba Bay, São Paulo, abiotic factors that correlated with the occurrence of the "espigudo" were temperature, salinity, and the composition of the marine substrate, the latter being the most relevant (COSTA et al., 2007). Andriguetto-Filho et al. (2016) concluded in their studies on the coast of Paraná that the "espigudo" is greatly influenced in its distribution by the rainy season, which enhances estuarine conditions. Distribution of this shrimp was also correlated to temperature, salinity and water transparency, as parameters that directly interfere with the life cycle of these shrimps. In the tropical region studied in this article, Lucena to Costinha, the temperature did not interfere with the distribution of the species, in contrast to the previous studies, conducted in the south of the country, because in the study area, temperatures were similar along the year.

At L3, environmental variables are directly influenced by the tides and the river dynamics with its fluvial influx. The months in which the largest sightings of white shrimp registered were October, November, and December, 2014. This increase coincides with the reduction of the fluvial influx (Figure 10). The salinity varied from 31 to 36 at this location. Ammonium presented high concentrations, between 115.33 and $323.11\left(\mathrm{mg} / \mathrm{L}^{-1}\right)$, the DO varied from 9.5 to $11.5\left(\mathrm{mg} / \mathrm{L}^{-1}\right)$, and the nitrite varied from 0,43 to 4,36 (mg/L $\left./ \mathrm{L}^{-1}\right)$. In the estuary of Rio Formoso, Pernambuco, the highest densities of white shrimp were recorded immediately following the months of highest precipitation. These environmental conditions in estuaries are determinant for the distribution of the white shrimp (SILVA et al., 2006). Other studies cite the months of August and September as presenting the highest frequencies of white shrimp along the coast of Brazil (SEVERINO-RODRIGUES et al., 1992; COELHO; SANTOS, 1995), which agrees with the results obtained in this article. 
Figure 8 - Graph of the precipitation (mm) and abundance of the two species of shrimp in L1, during years of 2014 and 2015

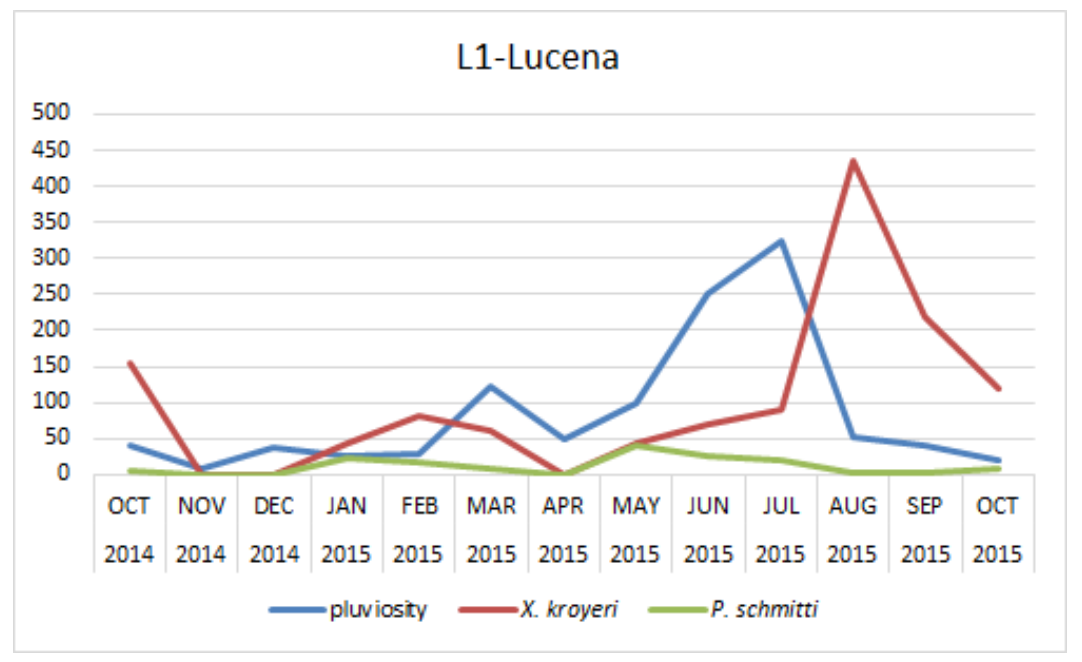

Figure 9 - Graph of the precipitation (in $\mathrm{mm}$ ) and abundance of the two species of shrimp in L2, during the years of 2014 and 2015

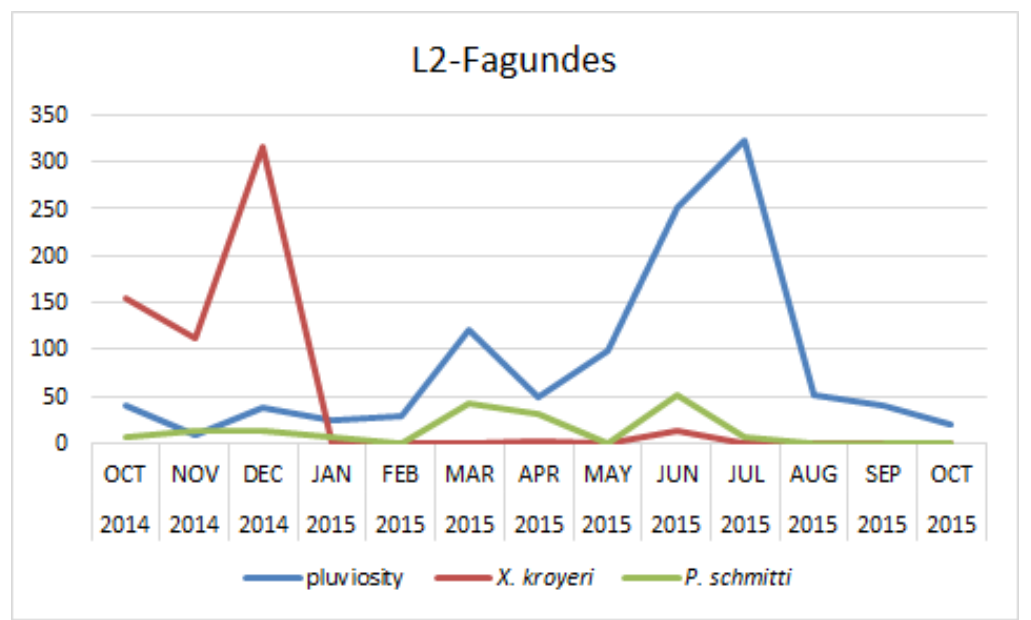

Figure 10-Graph of the precipitation (in mm) and abundance of P. schmitti em P3 during the years of 2014 and 2015.

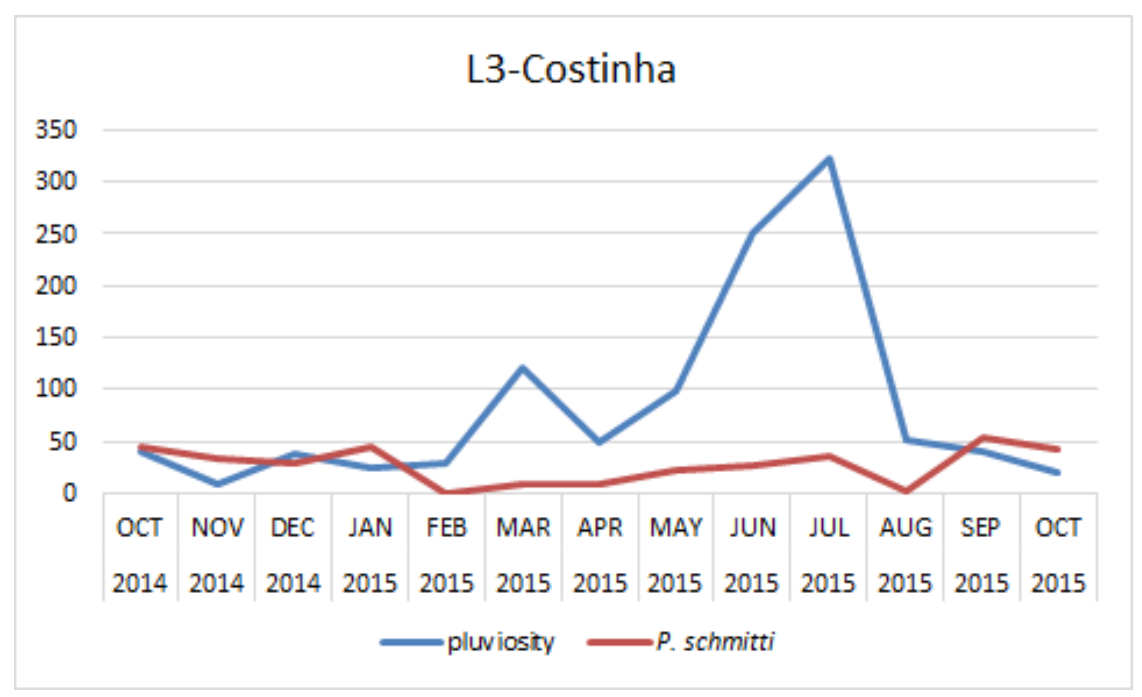




\section{Conclusions}

The characterization of the fishing types for the capture of shrimps in the municipality of Lucena produced relevant information on species caught, as well as on the behavior and dynamics of the environments that were studied, showing two fishery types, and shrimp population dynamics along the year. The importance of shrimp fishing for artisanal communities is well known. In L1 (Lucena) was the shrimp fishing is predominated by the use of drag-nets along the beach, for both the white shrimp and the "espigudo". In L2 (Fagundes) was characterized by irregular fishing activity, comparing with L1 and L3, and in L3 (Costinha) in shrimp fishing only one of the species, the white shrimp, is caught but with a different tool with shrimp nets hauled from boats and drag-nets were not used.

Precipitation significantly affected the shrimp species in the studied area, together with other variables related to the rainy season such as nitrogenous nutrients.

Fishery recruitment for the species studied, mainly during the rainy season, May, June and July, while for the white shrimp recruitment occurs mainly in October and November.

\subsection{Final remarks}

Economic groups are planning an installation of a major shipyard at L3 (Costinha). This has the potential to cause great physico-chemical changes in the studied estuarine area. Such anthropic action may result in irreparable environmental losses for the all biota inhabiting the area, including shrimps. These changes have the potential to entirely extinguish the fishing activities presently so vital for the artisanal communities in these surroundings.

The increase in eutrophication and nitrogenous compounds has the potential to favor the "espigudo", to the detriment of the white shrimp, since the former species showed, in this work, be more resistant than the white shrimp to increase in water nutrient concentration.

It seems pertinent to stress the absence of public policies for dealing with the shrimp fishing activities in the State of Paraíba. More effective action is necessary, with the possibility of establishing of periods when fishing operations are banned during the reproductive periods of these shrimps. Overall management of the fishing activities is fundamental for those communities directly dependent on these fishing practices. Fishermen whose livelihood depends on shrimp fishing should be involved in such management initiatives. Furthermore, more effective controlling measures should be directed to the Rio Paraíba estuary, aiming to preserve the rich marine biota that depends on this system for completing the life cycles of the shrimp and which directly provide food resources for the artisanal communities living there.

\section{Acknowledgments}

We acknowledge CAPES (Coordenação de Aperfeiçoamento do Ensino Superior) for the Ph.D. scholarship provided to the first author and LABEA (Laboratório de Ecologia Aquática) for providing laboratory space. We thank all the fishermen from Lucena that partipated in this Project and showed us part of their world and daily survival efforts.

\section{References}

ANDRIGUETTO-FILHO JM, NATIVIDADE CD, BRANDINI FP, TEIXEIRA RA. Local hydrography and fishing drive life cycle strategies and population dynamics of the sea-bob shrimp Xiphopenaeus kroyeri in a coastal subtropical environment in Brazil. Hydrobiologia. 2016;771(1):207-225.

BAIL GC, BRANCO JO. Pesca artesanal do camarão sete-barbas: uma caracterização sócio-econômica na Penha, SC. Braz. Journ. Aquat. Sci. Technol. 2007;11(2): 25-32.

BRANCO JO. Biologia e pesca do camarão Sete-Barbas (Xiphopenaeus kroyeri) (Heller) (Crustacea, Penaeidae), na armação do Itapocoroy, Penha, Santa Catarina, Brasil. Rev. Bras. Zool. 2005;22(4):1050-1062.

BASTOS R, FEITOSA FN. Caracterização de uma zona costeira tropical (Ipojuca-Pernambuco-Brasil): produtividade fitoplanctônica e outras variáveis ambientais. Braz. Jour. Aquati. Sci. Technol. 2011;15(1):01-10.

BATE CS. Report of the Crustacea Macrura collected by the H.M.S. "Challenger" during the years 1873-1876. Report on the Scientific Results of the Voyage of H.M.S. Challenger During the Years 1873-1876. Zool. 1888;24:1-942. 
BOCHINI GL, FRANSOZO A, HIROSE GL, COSTA RC. Temporal and spatial distribution of the commercial shrimp Litopenaeus schmitti (Dendrobranchiata: Penaeidae) in the south-eastern Brazilian coast. Journ. Mar. Biol., Association of the United Kingdom. 2014;94(5):1001-1008.

BRANDINI FP, SILVA AS, SILVA ET, KOLM H. Sources of Nutrients and Seasonal Dynamics of Chlorophyll in the Inner Shelf off Paraná State - South Brazil Bight. Journ. Coas. Res. 2007;23(5):1131-1140.

CASTRO RH, COSTA RC, FRANSOZO A, MANTELATTO FLM. Population structure of the seabob shrimp Xiphopenaeus kroyeri (Heller, 1862) (Crustacea, Penaeoidea) in the litoral of São Paulo, Brazil. Scien. Mar. 2005;69(1):105-112.

COELHO PA, SANTOS MCF. Época da reprodução do camarão-sete-barbas, Xiphopenaeus kroyeri (Heller, 1862) (Crustacea, Decapoda, Penaeidae) na região de Tamandaré, PE. Bol. Técn. Cient. Centr. Pesq. Nord. 1993;1(1):171-186.

COELHO PA, SANTOS MCF. Época da reprodução dos camarões Penaeus schmitti Burkenroad, 1936 Penaeus subtilis PérezFarfante, 1967(Crustacea: Decapoda: Penaeidae), na foz do rio São Francisco (AL/SE). Bol. Técn. Cient. Centr. Pesq. Nord. 1995;3(1):121-140.

COSTA RC, FRANSOZO A, FREIRE FAM, CASTILHO AL. Abundance and Ecological Distribution of the" Sete-Barbas" Shrimp Xiphopenaeus kroyeri (Heller, 1862) (Decapoda: Penaeoidea) in Three Bays of the Ubatuba Region, Southeastern Brazil. Gulf and Caribb. Res. 2007;19(1): 33-41.

CLESCERI AE, APHA LS, GREENBERG AD. Eaton. Standard Methods for the Examination of Water and Wastewater. American Public Health Association, Washington, DC. 1998;3-68.

DALL W, HILL BJ, ROTHLISBERG PC, SHARPLES DJ. The biology of Penaeidae. Adv. Mar. Biol. 1990;27:484.

DIAS NETO J, editor. Proposta de Plano Nacional de Gestão para o uso sustentável de Camarões marinhos do Brasil. 1st ed. Brasília: IBAMA; 2011.

FRANSEN C. Litopenaeus schmitti. World Register of Marine Species. 2015 [cited 2017 mar 10]. Available from: http:// marinespecies.org/aphia.php? $\mathrm{p}=$ taxdetails\&id $=582132$.

FERNANDES LJ, SASSI R, LIMA ERV. Gestão costeira e desenvolvimento urbano do município de Lucena (PB-Brasil): Uma proposta de planejamento ambiental usando o Processo Analítico Hierárquico. Rev. Gest. Cost. Int. 2011;11(2):219-232.

FERNANDES LP, KEUNECKE KA, DI BENEDITTO APM. Produção e Socioeconomia da pesca do camarão sete-barbas no norte do estado do Rio de Janeiro. Bolm. Inst. Pesca, São Paulo. 2014;40 (4):541-555.

GARCÍA MF, MEDEIROS S. O mar está pra peixe? Trabalho e natureza na pesca artesanal em Lucena, Brasil. Sémata: Ciên. Soc. Huma. 2013;25:179-204.

HAMMER Ø, HARPER DAT, RYAN PD. Paleontological Statistics Software: Package for Education and Data Analysis. Palae. Elect. 2001;4(1).

HARARI J, ABREU CVW. Texto adaptado do artigo "Estudo das relações entre as variabilidades do clima e da pesca desembarcada no estado de São Paulo. Programa em Ciência Ambiental. USP, São Paulo; 2007 [cited 2014 oct 15]. Available from: http://pesca.iff.edu.br/curso-de-especializacao-em-pesca-aquicultura-e-ambiente/meteorologia-aplicada-a-pesca/ artigos/Texto_adaptado_joseph_abreu.pdf.

HECKLER GS, SIMÕES SM, LOPES M, ZARA FJ, COSTA RC. Biologia Populacional e reprodutiva do camarão Sete-Barbas na Baía de Santos, São Paulo. Bol. Inst. Pesca São Paulo. 2013;39(3):283-297.

HOLTHUIS LB. Shrimps and prawns of the world. An annotated catalogue of interest to fisheries [Internet]. FAO Species Catalogue (FAO Fish. Syn.), Roma. 1980 [cited 2014 Mar 10]. Available from: http://www.fao.org/docrep/009/ac477e/ ac477e00.htm. 
INSTITUTO BRASILEIRO DE GEOGRAFIA E ESTATÍSTICA [Internet]. Paraíba, Lucena. 2010 [cited 2013 sep 03]. Available from: http://cidades.ibge.gov.br/xtras/perfil.php?lang=\&codmun=250860.

LOPES JBBS, VASQUES RO, GUIMARÃES FJ, CETRA M, COUTO ECG. Proporção sexual do camarão sete-barbas Xiphopenaeus kroyeri na costa de Ilhéus, Bahia, Brasil. Bol. Inst. Pesca, São Paulo. 2010;36(4):251-262.

LORENZEN CJ. Determination of chlorophyll and pheo-pigments: spectrophotometric equations. Limnol. Oceanogr. 1967;12(2):343-346.

MARTINS DEG, ZORRO MC, SOUZA-FILHO PWM, CINTRA IHA, SILVA KC. Spatial distribution of southern brown shrimp (Farfantepenaeus subtilis) on the Amazon continental shelf: a fishery, marine geology and GIS integrated approach. Braz. Journ. Oceanogr. 2015;63(4):397-406.

MENDONÇA TJ, BARBIERI E. A pesca do camarão sete-barbas Xiphopenaeus kroyeri no município de Cananéia-SP entre 1998 e 1999. Braz. Journ. Aqua. Scien. Tech. 2010;4(1):77-90.

MOURA GF, MELO GN, SAMPAIO JAA. Estudos biométricos das espécies de camarões peneídeos de importância econômica no litoral de Lucena, Paraíba, Brasil. Bol. Técn. Cient. Centr. Pesq. Nord. 2003;11:189-210.

NORIEGA CD, COSTA KMP, FEITOSA FAN, MONTES MJF, GREGO CKS, SOARES GS et al. Distribuição espacial da biomassa fitoplanctônica e sua relação com os sais nutrientes, no sistema estuarino de Barra das Jangadas (PernambucoBrasil). Arq. Ciênc. Mar. 2005;38(1-2):5-18.

PELIZZARI FM. Microfitobentos no sedimento arenoso da plataforma continental sueste do Brasil: composição geral, abundância e importância ecológica [dissertation]. Curitiba, PR: Setor de Ciências Biológicas/UFPR; 2000.

PÉREZ-CASTAÑEDA R, DEFEO O. Spatial distribution and structure along ecological gradients: penaeid shrimps in a tropical estuarine habitat of Mexico. Mar. Ecol. Prog. Ser. 2004;273:173-185.

PÉREZ-FARFANTE I, KENSLEY B. Penaeoid and Segestoid shrimps and prawns of the world. Keys and diagnoses for the families and genera. Memoires du Museum National d’ Histoire Naturelle (France); 1997.

PORTO HLR, FONTELES-FILHO AA, FREITAS CEC. Análise da biologia pesqueira do camarão branco, Penaeus schmitti Burkenroad, e do camarão vermelho Penaeus subtilis Pérez-Farfante, na ilha de São Luís, Estado do Maranhão. Bol. Lab. Hidro. 1988;8(1):97-115.

SANTOS MCF, RAMOS IV, FREITAS ANS. Análise de produção e recrutamento do camarão sete-barbas, Xiphopenaeus kroyeri (Heller, 1862) (Crustacea: Decapoda: Penaeidae), no litoral do Estado de Sergipe. Bol. Técn. Cient. Centr. Pesq. Nord. 2001;9(1):53 -71.

SANTOS JL, SEVERINO-RODRIGUES E, VAZ-DOS-SANTOS AM. Estrutura populacional do camarão-branco Penaeus schmitti nas regiões estuarina e marinha da Baixada Santista, São Paulo, Brasil. Bol. Inst. Pesca São Paulo. 2008;34(3):375-389.

SANTOS MCF, COELHO PA, PORTO MR. Sinopse das informações sobre a biologia e pesca do camarão sete-barbas, Xiphopenaeus kroyeri (Heller, 1862) (Decapoda, Penaeidae), no nordeste do Brasil. Bol. Técn. Cient. Centr. Pesq. Nord. 2006;14(1):141-178.

SANTOS MCF, BRANCO JO, BARBIERI E. Biologia e pesca do camarão Sete-Barbas nos estados nordestinos brasileiros onde não há regulamentação do período de defeso. Bol. Inst. Pesca São Paulo. 2013;39(3):217-235.

SILVA GS, BRITO VB, NASCIMENTO AE, CAMPOS-TAKAKI GM. Águas estuarinas e sustentabiliadde social local: um estudo da pesca artezanal do camarão-branco Penaeus schmitti Crustacea, Decapoda, Penaeidae) no estuário do Rio Formoso, Pernambuco, Brasil. Rev. Biol. Ciênc. Terra. 2006;1(Suppl Esp.):40-47.

TEOH HW, LEE SL, CHONG VC, YURIMOTO T. Nutrient (N, P, Si) concentration and primary production on a perturbed tropical coastal mudflat. Env. Earth Sci. 2016;75(15):1147. 
TROTT LA, ALONGI DM. Variability in surface water chemistry and phytoplankton biomass in two tropical, tidally dominated mangrove creeks. Mar. Fresw. Res. 1999;50(5):451-457.

VIANA DF, CAMARGO E, DUTRA GF. Avaliação econômica da pesca do camarão sete-barbas, Xiphopenaeus kroyeri (HELLER, 1862), no município de Caravelas-BA, BRASIL. Bol. Inst. Pesca São Paulo. 2015;41(2):419-428.

VOGT G. Ageing and longevity in the Decapoda (Crustacea): A review. Zool. Anz. 2012;251:1-25.

SOUSA GS, COCENTINO ALM. Macroalgas como Indicadoras da Qualidade Ambiental da Praia de Piedade-PE. Trop. Ocean. 2004;32(1):1-22.

ROBERT R, BORZONE CA, NATIVIDADE CD. Os camarões da fauna acompanhante na pesca dirigida ao camarão-setebarbas (Xiphopenaeus kroyeri) no litoral do Paraná. Bol. Inst. Pesca São Paulo. 2007;33(2):237-246.

SEVERINO-RODRIGUES E, PITA JB, GRALÇA-LOPES R, COELHO JAP, PUZZI A. Aspectos biológicos e pesqueiros do camarão sete-barbas (Xiphopenaeus kroyeri) capturado pela pesca artesanal do litoral do Estado de São Paulo. Bol. Inst. Pesca. São Paulo. 1992;19(1):67-81.

WHEELER PA, KOKKINAKIS SA. Ammonium recycling limits nitrate use in the oceanic subarctic Pacific. Limnology and Oceanography. 1990;35(6):1267-1278.

YIN K, QUIAN PY, CHEN JC, HSIEH DPH, PAUL J. Dynamics of nutrients and phytoplankton biomass in the Pearl River estuary and adjacent waters of Hong Kong during summer: preliminary evidence for phosphorus and silicon limitation. Mar. Ecol. Prog. Ser. 2000;194:295-305.

\section{Glória Cristina Cornélio do Nascimento \\ Pós Graduação em Desenvolvimento e Meio Ambiente - PRODEMA, Universidade Federal da Paraiba - UFPB, Paraiba, Brasil E-mail: gccornelio@hotmail.com}

Participação do autor: Realizou contribuições substanciais para a concepção do trabalho e redação

\section{Dimitri de Araújo Costa}

Pós Graduação em Desenvolvimento e Meio Ambiente - PRODEMA, Universidade

Federal da Paraíba - UFPB, Paraíba, Brasil

E-mail: costa.researcher@yahoo.com.br

Participação do autor: Realizou análise e interpretação de dados estatísticos

\section{Raquel Ferreira de Sá}

Centro de Ciências Exatas e da Natureza-CCEN, Universidade Federal da Paraíba $U F P B$, Paraíba, Brasil

E-mail: raquel.ufpb@hotmail.com

Participação do autor: Realizou análise e interpretação de dados estatísticos

\section{Martin Lindsey Christoffersen}

Departamento de Sistemática e Ecologia , Centro de Ciências Exatas e da NaturezaCCEN, Universidade Federal da Paraíba - UFPB, Paraíba, Brasil

E-mail: martinlc.ufpb@gmail.com

Participação do autor: realizou revisão substancial e redação

\section{Maria Cristina Basilio Crispim}

Departamento de Sistemática e Ecologia , Centro de Ciências Exatas e da NaturezaCCEN, Universidade Federal da Paraiba-UFPB, Paraíba, Brasil

E-mail: crispim@hotmail.com

Participação do autor: Realizou orientação, revisão substancial e redação 